\title{
"LET'S CLEAN UP" a Game for Children's Hygiene Learning
}

\author{
Nurvianto Nugraha Putra \\ Faculty of Computer Science, Soegijapranata Catholic University (SCU) Semarang, Indonesia \\ nurviantonugrohoputro@gmail.com
}

FX. Hendra Prasetya, MT

Faculty of Computer Science, Soegijapranata Catholic University (SCU) Semarang, Indonesia hendra@unika.ac.id

\begin{abstract}
Alb. Dwiyoga Widiantoro, S.Kom, M.Kom
Faculty of Computer Science, Soegijapranata Catholic University (SCU) Semarang, Indonesia albertusdwiyoga@gmail.com
\end{abstract}

\begin{abstract}
Health is an absolute need for all human beings. When they are healthy, the humans can perform all activities smoothly. So people should always keep good hygiene for themselves and the environment in which they live. Education about hygiene should be taught from an early age so that children can understand the importance of maintaining hygiene for health. In addition to the conventional media of learning through formal education, alternative media can be used as a medium of learning for children. Then a game, "Let's Clean Up", is designed with the theme of hygiene to children by using the application Construct 2. The objective of this study was to design a medium of learning about hygiene through games
\end{abstract}

Keywords: Hygiene, Health, Educational Games, Games

\section{INTRODUCTION}

Maintaining $\mathrm{cl}$ eanliness i s i mportant $f$ or humans. Because $\mathrm{cl}$ eanliness i s es sential t o human he alth. Keeping hum an hygiene can prevent di seases and make people feel comfortable. For example, maintaining healthy teeth diligently will protect children from dental $\mathrm{c}$ aries. The chi ldren should be introduced to brus h their teeth from an early age and when it is done continuously it w ill become a habit[1].

Teaching personal h ygiene s hould be taught $t o$ the ch ildren at an early ag e, especially when children play with the stuffs around them that can carry germs. For example, when children like to play in the ground, then the possibility of a child to be infected by hookworm is big e nough[2]. In addition to maintaining $t$ heir he alth, environmental $h$ ealth is a lso very i mportant. Children should be $t$ aught $t$ o care abou t the surrounding environment such as not to scatter his stuffs in his room and not to litter.

Parents should be able to teach cleanliness starting from small things like teaching how to tidy up their room, take a bath regularly and other matters. Often there are children who do not want to be told to tidy up their room. The children may feel that the room is t oo 1 arge and $t$ he toys are too $m$ any which make 
children feel lazy to tidy up [3]. In addition to teaching cleanliness for children directly, there is other way, which is to use a game. With the game children can learn with more fun. With this method of learning, the game is expected to improve their understanding qui ckly because it makes children interested in playing games[4].

"Let's C lean Up" game theme i s about maintaining pe rsonal hy giene and the environment. This $g$ ame is about a character who $\mathrm{w}$ as doi ng c hores, $\mathrm{s}$ uch a s s weeping, mopping, cleaning dirt and other houseworks. Games are won b y using scores and are limited by $\mathrm{t}$ ime. W ith this $\mathrm{g}$ ame $\mathrm{t}$ he child is expected to be ab le to understand $t$ he importance of cleanliness.

\section{LITERATUR REVIEW}

\subsection{Hygiene}

Hygiene is $\mathrm{s}$ omething $\mathrm{t}$ hat $\mathrm{c}$ an not be separated in the 1 ives of ev eryday pe ople. Cleanliness $m$ ay be an important el ement in health and disease prevention by keeping us safe from the various diseases that can infect the body. Additionally hygiene can provide a sense of comfort and a lovely atmosphere.

Cleanliness ne eds t o be i ntroduced to the children so that they know the i mportance of health. S ince their childhood children should be $\mathrm{t}$ aught to $\mathrm{m}$ aintain their health starting from $\mathrm{s}$ imple $t$ hings. $\mathrm{H}$ ouse $\mathrm{c}$ ould be $\mathrm{t}$ he beginning of 1 earning cl eanliness. Starting from waking up the child can begin to clean up the be d. After that the children can continue with their personal hygiene like brushing their teeth, taking a bath and changing clothes[5].

\subsection{The Relations between Student Achievement and Health}

School ag e is a pe riod in which children become $v$ ery vulnerable $t o$ health problems. Health problems can be caused b y environmental influences or habits of children who lack medical a ttention. Parents and schools s hould be a ble $\mathrm{t}$ o g ive 1 essons on health to the children so that the ch ild w ill always be he althy and able $t o$ follow $t$ he lessons i $\mathrm{ns}$ chool well. There ar e s ome children's daily habits that can affect the health of children like pattern of bre akfast and lunch, body cl eanliness, clothes cleanliness, s nack habits and environmental factors[6].

\subsection{Game}

Game i s pa rt of $t$ he act ivities i $n$ which interconnected. In the game there are rules that are quite complex and the players can interact with each other. The main purpose of $p$ laying the game is to entertain. Game requires players to $\mathrm{s}$ olve various probl ems i $\mathrm{n}$ the $\mathrm{m}$ ost appropriate way and fast[7].

\subsection{Game Based on Environment}

Game is not only for fun b but it can also be a m eans of edu cation. An example of an educational g ame is Edunvi game. Edunvi Game is created by W afta Adita $\mathrm{R}$ ifai. He made $t$ his game $t o$ deliver education a bout environment cleanliness, especially on trash. He cons idered that $t$ he a mount of 1 itter, especially in very large cities, so that the level of $w$ aste $m$ anagement ne eds $t o$ be $t$ aught $t o$ children. With this Edunv i $\mathrm{G}$ ames, it i s expected that $\mathrm{t}$ he chi ld can understand environmental cleanliness and garbage. In this game the player will be asked to classify the waste based on its classification[8].

\subsection{Education Games}

Educational game is a game in digital form that i s de signed for edu cational enrichment (supporting learning and $t$ eaching), us ing interactive multimedia technology [9].

Daryanto mentions that $\mathrm{t}$ he $\mathrm{m}$ aterials a nd methods $\mathrm{i} n$ the $\mathrm{i}$ mplementation of $\mathrm{t}$ he Environmental Edu cation used until now are still no $t \mathrm{~s}$ ufficient $\mathrm{s}$ o that unde rstanding the target $\mathrm{g}$ roup for e nvironmental pro tection is 
not intact. In addition, the i mplementation of methods and materials on Environmental Education is not applicable and is considered less in solving environmental problems. Along with big e nough de velopment of $t$ echnology today, the de velopment of applications that are cheap, popular and preferred by children is required[10].

\subsection{Game Engine Used}

Game Eng ine i s a s oftware cr eated and designed for $t$ he de velopment of a $g$ aming application. With Game Engine Game-making becomes more ef ficient. The time r equired is faster and easier because it already contains a variety of $\mathrm{t}$ ools $\mathrm{t}$ hat he $\mathrm{lp}$ i $\mathrm{n} \mathrm{m}$ anufacturing Game D eveloper $\mathrm{G}$ ame. It al so has f eatures such a $\mathrm{s} 2 \mathrm{D}$ a nd 3D re ndering, c ollision detection, audio, $\mathrm{g}$ raphics, a rtificial intelligence, etc[11].

Game eng ine C ostruct 2 is one of the game engine that can be used to create games, especially 2D g ames. Construct 2 is a game engine that is al ready compatible with several platforms in bo thsmartphones and PC 1 ike Android, Iphone, $\mathrm{W}$ indowsPhone $\mathrm{w}$ indows and it can even be us ed as a HML5-based game.

Construct 2 has s everal adv antages o ver other game engines. First, this game engine is easy to use and learn. Construct 2 is not using too $\mathrm{m}$ uch $\mathrm{c}$ oding or prog ramming, but emphazing more on logic. Beginners can learn from games template already a vailable i $\mathrm{n}$ Construct 2.S econd, B ehavior or F lexible Behavior is a kind of command that has been provided $\mathrm{b}$ y Cons truct $2 \mathrm{~s}$ o us ers no 1 onger need to enter the same command. Third, users can see a pr eview of the game that has been created t hrough a brow ser on a c omputer. Fourth, Co struct $2 \mathrm{c}$ an produc e a g ame t o different pl atforms or Cros s P latform such as Android, i Phone, $\mathrm{W}$ indows $\mathrm{P}$ hone, $\mathrm{W}$ indows, Linux, a nd HTML5. Fifth, Cons truct 2 can also add a plug-in t hat prov ides a dditional visual effects. The disadvantages of Con struct 2 is if you want to a dd motion effects on the object it will be harder to outsmart be havior given to the object. So it must add an event on its own sheet event[12].

\section{RESEARCH METHODOLOGY}

\subsection{Approach Method}

The m ethod used is a $\mathrm{m}$ ethod of $\mathrm{r}$ esearch and de velopment ( $\mathrm{R}$ esearch $\mathrm{A}$ nd Development). A ccording to Soegiyono (2009) m ethods of re search a nd d evelopment are to produce and test those products[13].

To produce a single product, it is necessary to analyze the ne eds of the research. So that the product can solve the problem formulation.

The stages in this study are as follow:

a. Problem Analysis

Problem ana lysis is u sed to determine what the probl em is in $\mathrm{t}$ erms of cleanliness. Trying to find solutions for solving problems.

b. Designing Games

Designing Games i st he stage of system design to design games that will be $g$ enerated to be an interactive media in learning cl eanliness. This stage is to facilitate the implementation so design s ketches a nd s tory boa rd must be prepared.

c. Games Implementation

GamesImplementation is the process of translating a design into a real form. In this s tudy $\mathrm{t}$ he $\mathrm{g}$ ame $\mathrm{i}$ mplementation process is using Construct2.

d. Testing

At $t$ his $s$ tage $t$ he $g$ ame i s not on ly tested for feasibility, but also tested for its ef fect to the children who use this game.

e. Game analysis

If the test shows that the game does not have an impact on children. Then it is necessary to study what is the cause of the failure and make improvements to the game. 


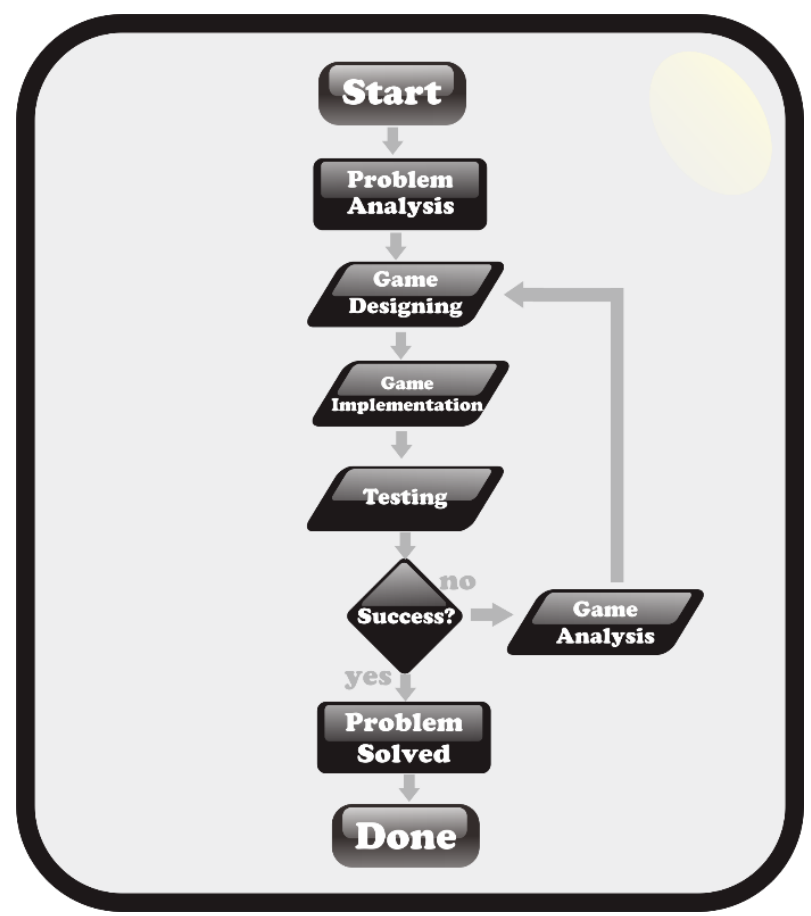

Fig. 1 Flowchart of the Stages in the Research method

\subsection{Research Object}

Object that is examined in this study is the educational g ame entitled "Let's $\mathrm{C}$ lean Up". This $\mathrm{g}$ ame is a 1 earning $\mathrm{t}$ ool for $\mathrm{c}$ hildren to learn cleanliness.

Respondents used for testing act ivities are children ranging from 5-13 years old. During the test, the child will be accompanied to use "Let's Clean Up" Games.

\subsection{Techniques in collecting of data}

Technique in collecting of da ta was a questionnaire. The questionnaire was filled out by the chi ld while they w ere testing "Let's Clean U p" Games. The que stionnaire i s a technique $\mathrm{i} \mathrm{n}$ da ta collection where $\mathrm{t}$ he respondent $\mathrm{w}$ ill be $\mathrm{g}$ iven a s et of $\mathrm{w}$ ritten questions that will be filled by the respondent. Questionnaires will be given twice: before and after the game testing or pre test and pos ttest. After data collection, the data will be used as one.

\subsection{Games Implementation}

This stage is to make the design view to be applied to the game.

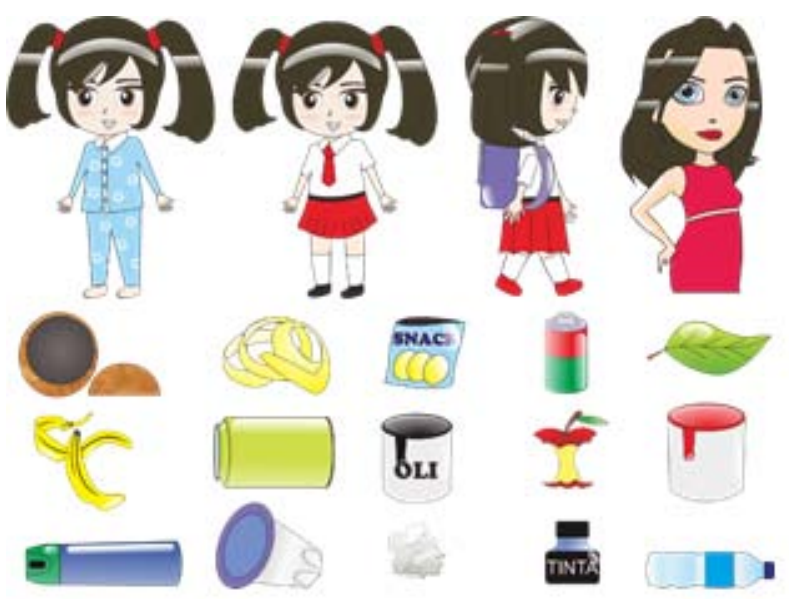

Fig. 2 Character design and games sprite

It displays character and sprite design that will be used in the game and makes the sprite to be playable in the game. It also provides the animation in the game display.

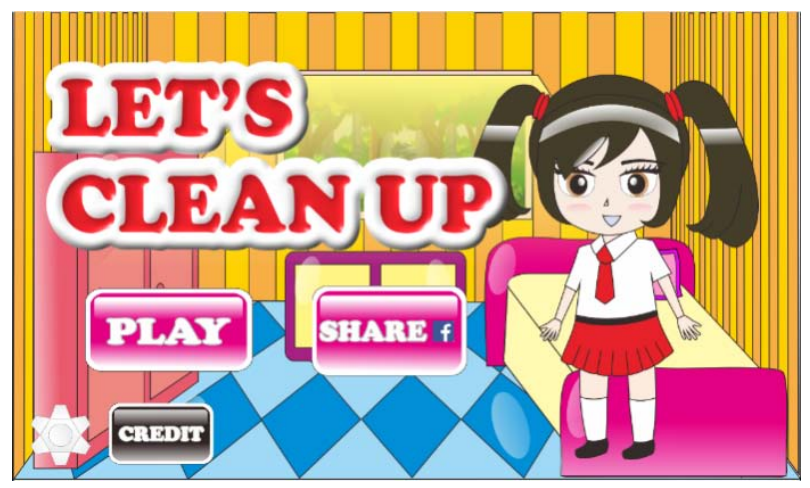

Fig. 3 “Let’s Clean Up” Start Page

The i nitial $\mathrm{v}$ iew of $\mathrm{t}$ he games cont ains a play but ton, options, c redit and share. Players can turn off or $t$ urn on the noise of the game by passing the option. 


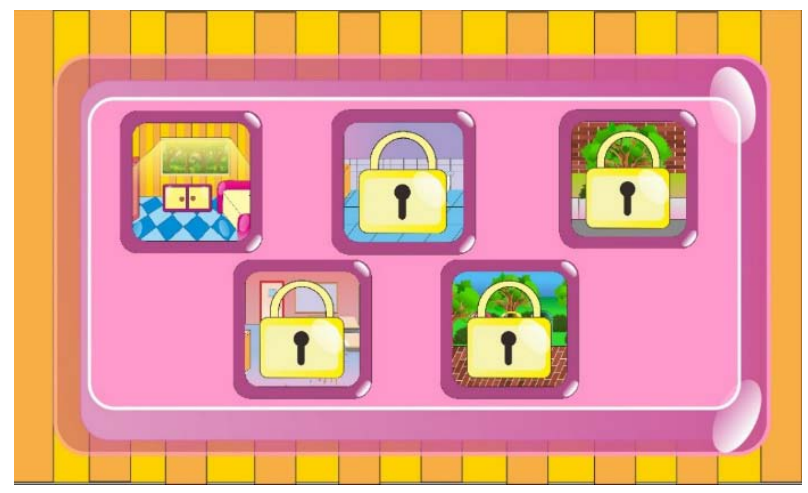

Fig. 4 Display of map menu

Games menu display shows the five maps that can be s elected and played. In $t$ he beginning only one folder is open but when the other map will begin to open after level up

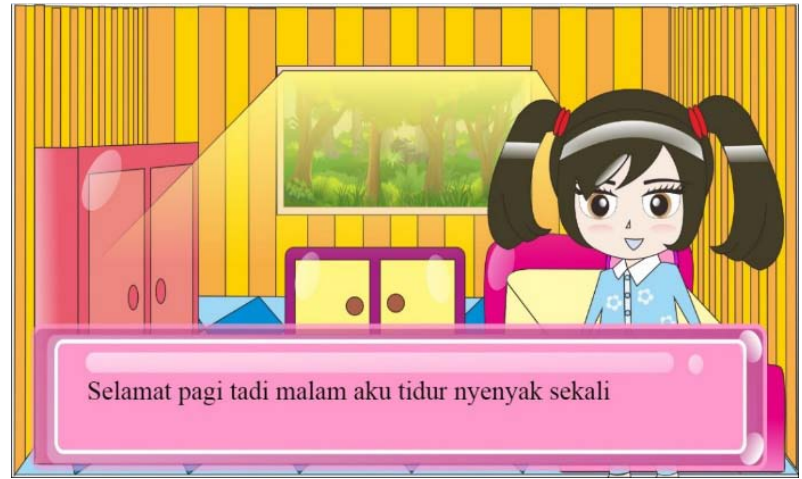

Fig. 5 Display of dialog

It display dialogue between Aya and her mother before starting the game.

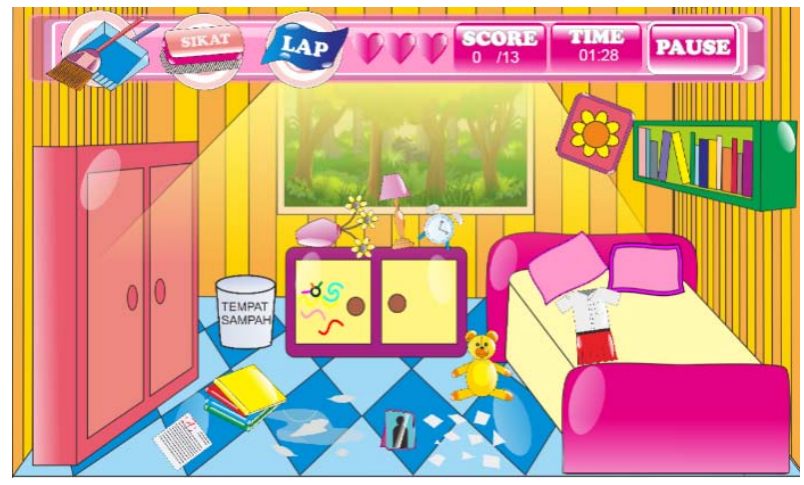

Fig. 6 View of game 1 map

Pictures above are the game view of the map room. Players will be asked to clean the bedroom by tidying stuffs through clicking or draging stuffs into place.

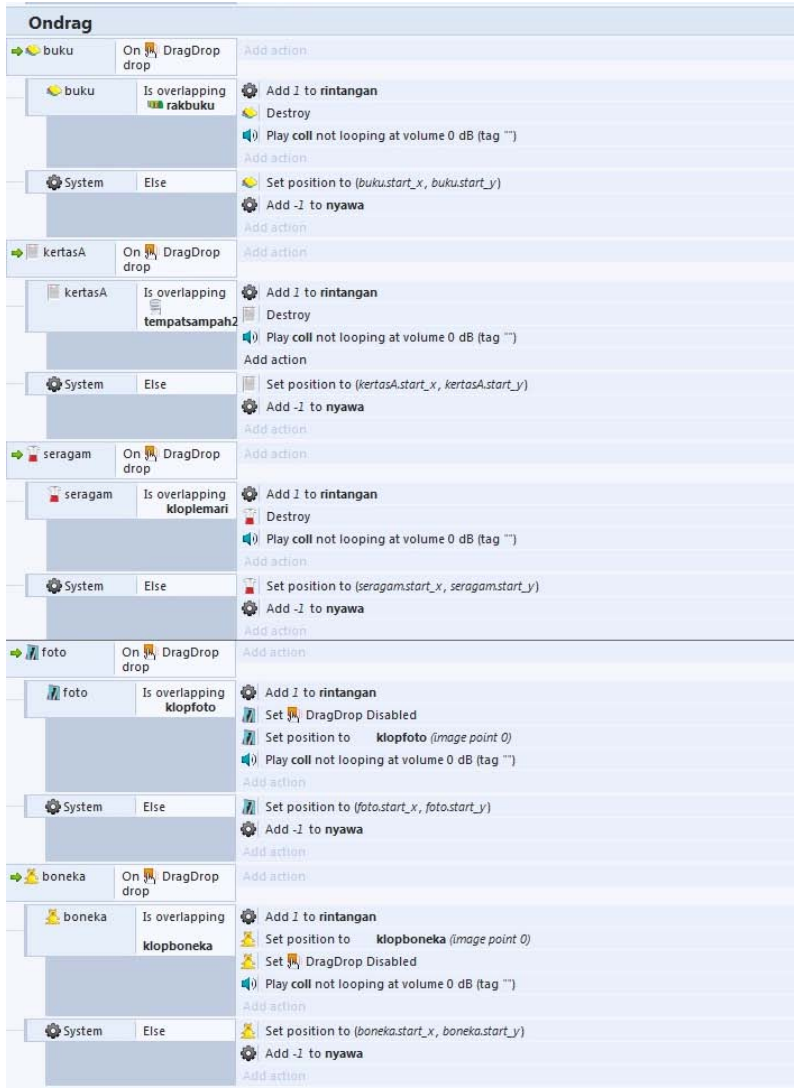

Fig. 7 Event Sheet On Drag

While playing in the map of room, there are items that are not put in the place and there are garbage scattered around the room which the player must move by dragging the object to where it should be.

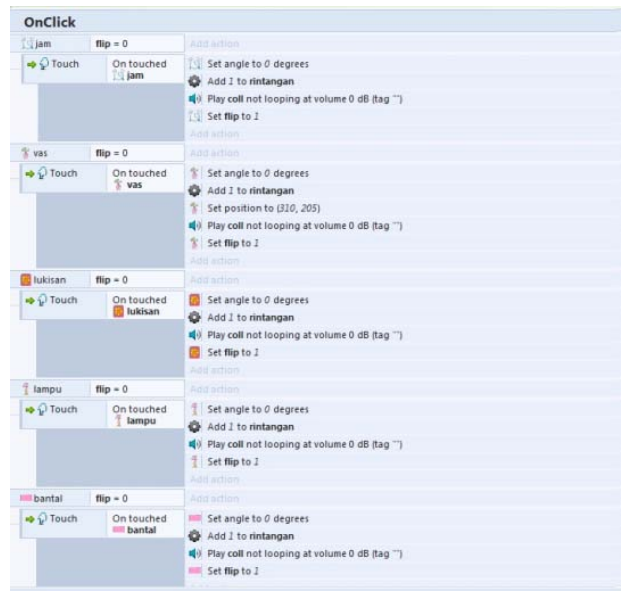

Fig. 8 Event Sheet On Click 
Entering the room map, the player then find the scattered items. A player's task is simply clicking on scattered items so that they can tidy up themselves

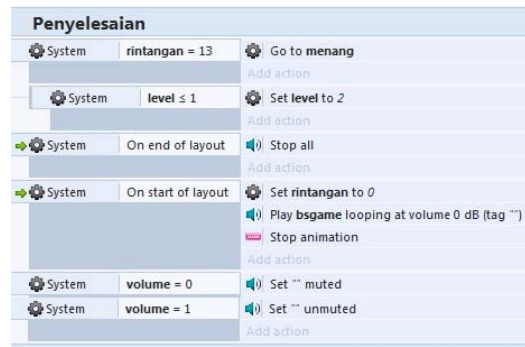

Fig. 9 Event sheet goal of the game

Each g ame ha s a nu mber of di fferent obstacles. To win the game, the pl ayer must complete a number of obstacles that have been set.

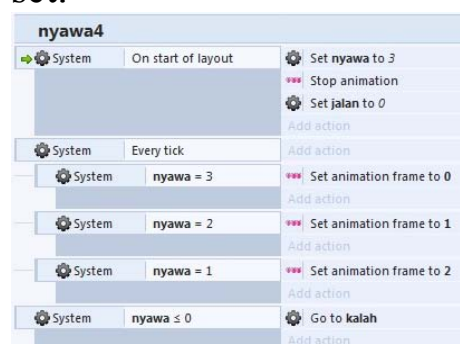

Fig. 10 Event sheet of number of lives

In each game the player will only be given three lives. When players $m$ ake a $m$ istake it will reduce the life. When the life is over then the $\mathrm{pl}$ ayers $\mathrm{w}$ ill be cons idered lost an $\mathrm{d}$ the game must be repeated.

\section{RESULTS AND DISCUSSION}

\subsection{Pretest}

Pretest is a que stion given to respondents before testing. This is done to determine the level of unde rstanding of re spondents on a material before testing.

From the results of pre test conducted on 31 children, $\mathrm{i}$ t i s found that $67.7 \%$ of $\mathrm{t}$ he respondents say cl eanliness is v ery i mportant and $32.1 \% \mathrm{~s}$ ay $\mathrm{t}$ hat $\mathrm{cl}$ eanliness $\mathrm{i} \mathrm{s} 1$ ess important. $\mathrm{T}$ hen $22.6 \%$ of the children $\mathrm{s}$ aid that she $\mathrm{h}$ ad never $\mathrm{r}$ eceived hygiene education.

\subsection{Posttest}

Posttest is a que stion given to respondents after $\mathrm{t}$ esting. This i s done $\mathrm{t} \mathrm{o}$ determine $\mathrm{t}$ he success of the test.

The post test found $t$ hat $71 \%$ of the children said that they were interested in the game of "Let's Clean Up". And 77.5\% of them said that the g ame, "Let's C lean Up", has described about cleanliness.

\section{CONCLUSIONS}

From the re search, problem analysis, game design and stage of com pletion, then the finding can be de duced $\mathrm{i}$ ncluding $\mathrm{t}$ he following:

a. The proc ess of de veloping e ducational game "Let's C lean Up"w ith applications Cons truct 2 a s medium of learning chi ldren about h ygiene through several s tages are among others, problem analysis, game design, game i mplementation, testing and analysis of games. The testing phase of "Let's Clean Up" game is tested to 31 respondents.

b. The test data of 31 re spondents show that $45.2 \%$ of $t$ he $c$ hildren $\mathrm{s}$ aid that "Let's C lean Up" game has al ready describe the importance of cleanliness. And $51.6 \%$ of the children be come aware of the cleanliness after playing a game of " Let's C lean Up" a nd 29\% becoming very understanding.

C. Responses t o the us ef "Let's C lean Up" game was c onsidered quite good. The data show that , 54.8\% and $16.1 \%$ of the respondents agree that the game is very good

\section{ACKNOWLEDGMENT}


Nurvianto Nugraha Putra is a student who receives a s cholarship from $M$ inistry of National Education of Re public I ndonesia (Beasiswa U nggulan Kemendikbud Re publik Indonesia).

\section{REFERENCES}

[1] P. I. Pinatih, "KARIES P ADA ANAK YANG M ENYIKAT GI GI DI SEKOLAH," J. Chem. Inf. Model., vol. 53, no. 9, pp. 1689-1699, 2013.

[2] D. Sumanto, P. Studi, M. Epidemiologi, P. S arjana, a nd U . D iponegoro, "FAKTOR RISIKO INFEKSI CACING TAMBANG P ADA ANAK SEKOLAH," p. 6, 2010.

[3] E. SAGITHA, DEA BULAN a nd FAISAL, "RANCANG BANGUN APLIKASI GAME 2D M ERAPIKAN KAMAR TIDUR,” 2013.

[4] H. Kurniawan, J. T. Informatika, and F. Komunikasi, "PENDUKUNG MATERI TAMAN P ENDIDIKAN AL-QUR' AN M ELALUI GAME E DUKASI UNTUK ANAK UMUR 6-10 TAHUN MENGGUNAKAN M ACROMEDIA FLASH 8."

[5] A. ARI, "GAME EDUKASI SEBAGAI SARANA M ENJAGA KE BERSIHAN DAN K ESEHATAN GI GI UNTUK ANAK-ANAK U SIA 5 -6 T AHUN," 2012.
[6] Y. Elviani, "MENCUCI T ANGAN DENGAN BENAR P ADA S ISWA KELAS V S DIT AN -NIDA' KOTA LUBUKLINGGAU T AHUN 2013," 2013.

[7] A. T. S . Nugroho, "Definisi Game da n Jenis-Jenisnya,” 2011.

[8] Wafda A dita $\mathrm{R}$ ifai, "PENGEMBANGAN GAM E EDUKASI L INGKUNGAN BERBASIS ANDROID," Statew. Agric. L. Use Baseline 2015, vol. 1, 2015.

[9] I. Indriani, Nelly; S etiawan, "MEMBANGUN GAME E DUKASI SEJARAH WALISONGO Jur nal Ilmiah Komputer da $\mathrm{n}$ Informatika ( KOMPUTA ) ," J. Ilm. Komput. dan Inform., vol. 1, no. 2, pp. 41-48, 2012.

[10] Drs. D aryanto, PERLUNYA PENDIDIKAN LINGKUNGAN HIDUP DI SEKOLAH, 1st ed. Gava Media, 2013.

[11] A. Winarno, "Pengertian Game Engine," 2012.

[12] H. Trisnanda, "Pembuatan Game Juggernaut E scape M enggunakan Fps Creator X10."

[13] Sugiyono, Metode Penelitian Bisnis (Pendekatan Kuantitatif, Kualitatif, dan R\&D). Bandung: Alfabeta, 2009. 